\title{
Diurnal rhythms of behavior and brain mRNA expression for arginine vasotocin, isotocin, and their receptors in wild Amargosa pupfish (Cyprinodon nevadensis amargosae)
}

\author{
Sean C. Lema, Lauren J. Wagstaff and Nina M. Gardner
}

\begin{abstract}
Amargosa pupfish (Cyprinodon nevadensis amargosae) occupy remote desert habitats that vary widely in environmental conditions from day to night. In this study, diel patterns of behavior were documented for pupfish in their natural habitat, and examined relative to changes in the abundance of mRNAs encoding prepro-arginine vasotocin (pro-VT), prepro-isotocin (pro-IT), three distinct vasotocin receptors (V1a1, V1a2, and V2), and an isotocin receptor (ITR) in the brain. The behavior of wild pupfish varied diurnally, with frequent aggression from 12:00 to 15:00 h and courtship and spawning most common between 15:00 and 19:00 h. Transcript abundance for pro-VT in the brain also changed diurnally with mRNA levels highest at night when the pupfish were least active. Transcripts encoding VT and IT receptors, however, exhibited distinct diel patterns, with $\mathrm{V}$ la 2 receptor transcripts showing sex-specific diurnal changes, but V2 receptor and ITR receptor mRNAs varying similarly for males and females. V1a1 and pro-IT transcript abundance were constant over day-night in both sexes. These results document diurnal variation in mRNAs encoding pro-VT and the $\mathrm{V} 1 \mathrm{a} 2, \mathrm{~V} 2$, and ITR receptors in the pupfish brain, and provide evidence that diel regulation of V1a2 receptor transcript abundance differs between males and females.
\end{abstract}

Keywords: vasotocin; AVT; isotocin; receptor; fish; Cyprinodon nevadensis amargosae; behavior; diel variation

\section{Introduction}

Many fish change their behavior in response to shifting environmental and social challenges from day to night (Helfman 1993; Thurow 1997). These behavioral changes can include shifts in vertical distribution (Sogard and Olla 1996; Adams et al. 2009), social interactions such as schooling, courtship, and spawning (Smith et al. 1993; Blanco-Vives and Sanchez-Vazquez 2009), feeding (Hibino et al. 2006), and general movement or swimming activity (Helfman 1993). Different taxa of fish vary widely in which behaviors show diurnal changes (Reebs 2002), and in some species, diel patterns have even been found to vary among individuals in accordance with social status or condition (Kadri et al. 1997). In giant kokopu (Galaxias argenteus), for example, dominant and subordinate fish show distinct 
diel patterns in foraging behavior, as the availability of high-quality foraging locations is partitioned differently from day to night according to agonistic dynamics (Hansen and Closs 2005). Taken together, the picture that is emerging from these and other studies suggests that diurnal behavioral variation is influenced by a variety of environmental factors including photoperiod, temperature, food availability, and even social cues such as dominance status, parental state, or predation risk (Fraser et al. 1993; Helfman 1993; Reebs 2002).

In fish, multiple endocrine pathways mediate the interacting influences of these physical and social environmental cues on diurnal variation in behavior. Primary among these endocrine pathways, melatonin secretion from the pineal organ has been demonstrated to regulate the daily behavioral rhythms in fish and other vertebrates (Falcón et al. 2007, 2010). Although melatonin serves as a key timekeeping molecule in fish, its effects on feeding, reproduction, and other behaviors are mediated through interactions with other neuroendocrine pathways (Falcón et al. 2007, 2010). Circulating levels of the peptide hormone arginine vasotocin (VT), for one, have been shown in several fish species to vary over a diel cycle (Kulczykowska and Stolarski 1996; Kulczykowska 1999). In fish, VT is a well-established regulator of both osmotic balance and hypothalamic pituitary-interrenal (HPI) axis stress responses (reviewed by Balment et al. 2006). More recently, VT has also been implicated as a regulator of sociosexual interactions in fish by modulating the propensity for a male to behave aggressively or court females (Semsar et al. 2001; Salek et al. 2002; Lema and Nevitt 2004a; Thompson and Walton 2004; Santangelo and Bass 2006; Walton et al. 2010). Neural VT-immunoreactive phenotype has now been shown to be associated with individual, population, and species-level variation in sociosexual behaviors in a variety of different fishes (Grober et al. 2002; Miranda et al. 2003; Larson et al. 2006; Lema 2006; Dewan et al. 2008), and prepro-vasotocin (pro-VT) mRNA levels in the preoptic area (POA) of the hypothalamus have been shown to differ between dominant and subordinate male African cichlids (Astatotilapia burtoni), suggesting that pro-VT transcript abundance in the brain can vary with social status (Greenwood et a1. 2008). Given these associations between sociosexual behaviors and the neural VT system in fish, we hypothesized that day-night cycles of behavior might also be underlain by diel changes in the neural VT system.

In this study, we documented diurnal variation in the abundance of gene transcripts encoding pro-VT, prepro-isotocin (pro-IT), and three newly identified VT receptors (V1a1, V1a2, and V2) (Lema 2010) - as well as a receptor for IT (ITR) - in the brain of Amargosa pupfish (Cyprinodon nevadensis amargosae) in a marsh habitat in the Death Valley region of California and Nevada, USA, and examined how these mRNA changes related to diel behavioral variation in the wild fish. Amargosa pupfish, like other pupfishes in the Death Valley region, occupy a series of remote streams and springs that are isolated by desert. Several of these habitats experience dramatic fluctuations in physical environmental conditions (i.e. temperature) throughout the day (Brown and Feldmeth 1971; Soltz and Naiman 1978), which lead the pupfish to shift their behavior and habitat use to cope with this diurnal environmental variability (Barlow 1958; Soltz 1974; Feldmeth 1981).

In previous work by Lema and Nevitt (2004a), VT was found to regulate aggressive behaviors in territorial male Amargosa pupfish (C. n. amargosae) in both the laboratory and the wild. Under both testing scenarios, administration of exogenous VT inhibited the initiation of aggressive interactions by male pupfish and 
increased the proclivity for males to retreat from agonistic interactions initiated by other fish (Lema and Nevitt 2004a). More recently, some populations of Amargosa pupfish (C. n. amargosae and C. n. mionectes) in Death Valley were found to have diverged evolutionarily both in aggressive behavior and the responsiveness of their neural VT systems to environmental conditions of salinity and temperature (Lema 2006). Together, these findings support the hypothesis that variation in the neural VT system in part underlies variation in aggressive behaviors both within and among - Amargosa pupfish populations (Lema 2006, 2008). In this study, we begin to explore whether the VT system might also contribute to diurnal changes in behavior within a population of $C$. $n$. amargosae by examining the diel variation in mRNA levels for pro-VT, pro-IT, and their receptors in the brain.

\section{Materials and methods}

\section{Study location and design}

Amargosa River pupfish (C. n. amargosae) were studied in the Amargosa River in San Bernardino County, CA, USA. The Amargosa River channel extends nearly $320 \mathrm{~km}$ before emptying onto salt flats on the floor of Death Valley. Over most of the Amargosa River's distance, however, the river is dry except following rainstorms, and pupfish are routinely located in only two small reaches of the river where the river's channel is fed by groundwater springs (for description, see Soltz and Naiman 1978). We studied pupfish from a small, spring-fed marsh $\left(35^{\circ} 53^{\prime} 08.42^{\prime \prime} \mathrm{N}, 116^{\circ} 14^{\prime}\right.$ $03.01^{\prime \prime} \mathrm{W}$ ) located adjacent to the upper permanent reach of the Amargosa River near Tecopa, California, USA. All studies were conducted from 2 to 3 June 2008. Water parameters in the marsh were recorded as $1.7 \mathrm{ppt}$ salinity and $11.52 \mathrm{mg} \mathrm{L}^{-1}$ dissolved oxygen (YSI 85, YSI Incorporated, Yellow Springs, OH, USA) over the experimental period. Temperature $\left({ }^{\circ} \mathrm{C}\right)$ and light intensity $\left(\operatorname{lum~} \mathrm{ft}^{2}\right)$ conditions were recorded at $2 \mathrm{~min}$ intervals throughout the experimental sampling period using HOBO $^{(B)}$ Pendant Temperature/Light Data Loggers (Onset Computer Corp., MA, USA). Temperature and light intensity profiles in the marsh over the $24 \mathrm{~h}$ study period are provided in Figure 1.

Over a $24 \mathrm{~h}$ period, we recorded pupfish behavior at several sampling locations within the marsh, and then immediately followed these observations with the collection of adult male and female pupfish for later quantification of brain transcript abundance for pro-VT, pro-IT, three pupfish vasotocin receptors (V1a1, V1a2, and V2), and an isotocin receptor (ITR). Behavioral observations and fish collection were coordinated around six sampling times: 04:00, 08:00, 12:00, 15:00, 19:00, and 23:00 h. This sampling method allowed us to document diel variation in pupfish behavior in the wild, as well as examine how behavior changed diurnally relative to neural transcript abundance for the VT-IT peptides and their respective receptors.

\section{Behavioral observations}

Six quadrats $\left(0.6 \times 0.6 \mathrm{~m}^{2}\right)$ were constructed on the substrate of the marsh using string connecting metal nails as corner posts. Quadrats were placed in the habitat 4 days prior to commencing behavioral observations, which gave the pupfish time to resume normal activities following the disturbance of quadrat construction. 


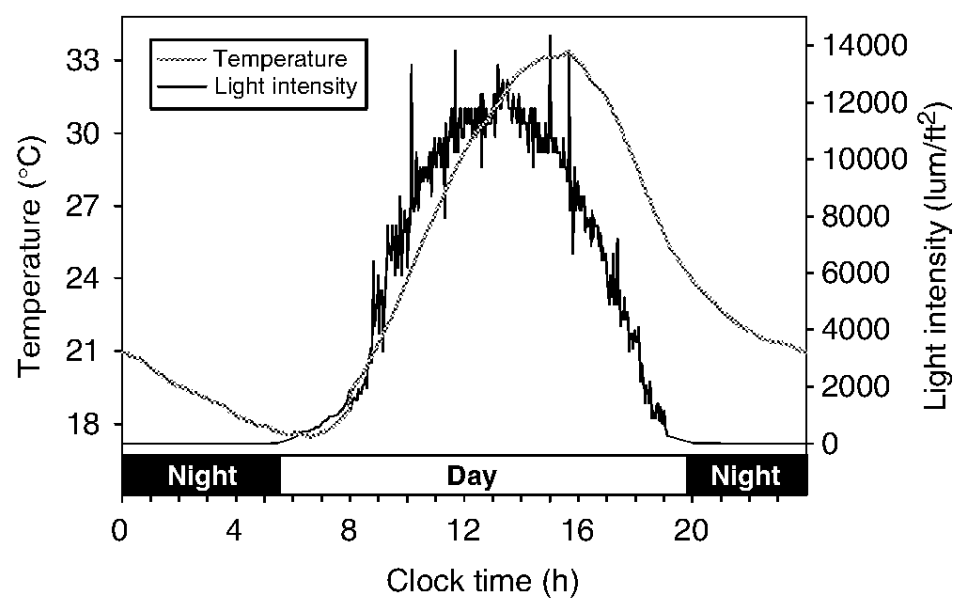

Figure 1. Mean temperature $\left({ }^{\circ} \mathrm{C}\right)$ and light intensity $\left(1 \mathrm{um} / \mathrm{ft}^{2}\right)$ conditions in the spring-fed marsh as recorded every $2 \mathrm{~min}$ by $\mathrm{HOBO}^{\circledR}$ Pendant Loggers over the $24 \mathrm{~h}$ period that Amargosa pupfish were studied. Water temperature showed a diel fluctuation that lagged behind insolation changes over the diel cycle. Day and night conditions, as demarked by the US National Ocean and Atmospheric Administration (NOAA) times (www.esrl.noaa.gov/ $\mathrm{gmd} / \mathrm{grad} / \mathrm{solcalc} /$ ) for sunrise and sunset at the study location, are shown as dark and light boxes above the $x$-axis.

The behaviors of pupfish were recorded within each of the six $0.36 \mathrm{~m}^{2}$ quadrats for a $2 \mathrm{~min}$ period immediately prior to fish collection. The number and species designation of fish located within each quadrat was recorded at the beginning and end of every 2 min observation period, to provide estimates of fish density. The Amargosa River is home to two native fishes - pupfish and speckled dace (Rhinichthys osculus) - as well as one invading species of mosquitofish (Gambusia affinis) (Soltz and Naiman 1978; Pister 1981). Speckled dace are generally not found in marshes with shallow, slow moving water, and were not observed in any of the quadrats. All behavioral observations were made immediately ( $\sim 20 \mathrm{~min})$ prior to the six sampling times during the $24 \mathrm{~h}$ period. These times were selected to provide a comprehensive picture of behavioral and physiological changes over a full day-night cycle.

During each behavioral sampling period, all aggressive, courtship, and feeding behaviors performed by pupfish within the quadrat were recorded. Descriptions of the behaviors that were observed are presented in Table 1; these behaviors were categorized according to motor pattern descriptions of the behavior of Amargosa pupfish and other closely related pupfishes (Barlow 1961; Liu 1969; Soltz 1974; Lema and Nevitt 2004a). For aggression, the recipient of the aggression - whether it was another pupfish or a mosquitofish - was also recorded. No instances of mosquitofish behaving aggressively toward pupfish were observed.

\section{Fish collection}

Adult male and female pupfish were collected by dip net at the six sampling times ( $n=4-9$ fish per sex and sampling time; total $N=76$ fish). Immediately after capture, fish were euthanized with tricaine methanesulfonate (MS222; Argent Chemical, Redmond, WA, USA) and measured and weighed. Brains were dissected and placed 
Table 1. Descriptions of pupfish behaviors recorded in this study.

\begin{tabular}{|c|c|}
\hline Behavior & Description \\
\hline \multicolumn{2}{|l|}{ Aggression } \\
\hline Charge & $\begin{array}{l}\text { Individual darts toward another fish with mouth open and median fins } \\
\text { folded }\end{array}$ \\
\hline Nip & $\begin{array}{l}\text { Individual darts toward another fish with mouth open and contacts the } \\
\text { other fish }\end{array}$ \\
\hline Display & $\begin{array}{l}\text { Males approach each other and momentarily pause face to face or side } \\
\text { to side with median fins spread }\end{array}$ \\
\hline \multicolumn{2}{|r|}{ - } \\
\hline Sidle & $\begin{array}{l}\text { Male swims alongside a female while contacting her pelvic fin region with } \\
\text { his snout }\end{array}$ \\
\hline Spawn & $\begin{array}{l}\text { Male and female lie side by side on the substrate with their bodies curved } \\
\text { forming an S-shape pattern; the anal fin of the male is wrapped around } \\
\text { the female's anal-genital region; usually followed by oviposition }\end{array}$ \\
\hline \multicolumn{2}{|l|}{$\begin{array}{l}\text { Additional } \\
\text { behaviors }\end{array}$} \\
\hline Feeding bite & Individual takes a mouthful of sand and/or algae from the substrate \\
\hline
\end{tabular}

in RNAlater (Applied Biosystems, Inc., Foster City, CA) at $4^{\circ} \mathrm{C}$ for $48 \mathrm{~h}$ before being stored at $-20^{\circ} \mathrm{C}$ until RNA extraction.

\section{Isolation and sequencing of cDNAs for pro-VT and pro-IT}

\section{Total RNA isolation}

A captively reared adult male Amargosa River pupfish (body mass, $5.30 \mathrm{~g}$; standard length, $54.00 \mathrm{~mm}$ ) was euthanized in MS222, and the whole brain with attached pituitary gland was dissected, frozen in liquid nitrogen, and stored at $-80^{\circ} \mathrm{C}$. Total RNA was extracted using Tri-Reagent (Molecular Research Center, Cincinnati, $\mathrm{OH}$ ) with bromochloropropane as the phase separation reagent. The sample was then DNase I treated (Invitrogen, Carlsbad, CA, USA), cleaned (RNeasy Kit, Qiagen, Valencia, CA, USA), and quantified by spectrophotometry (260:280 ratio of 1.98 ; NanoDrop Technologies, Wilmington, DE, USA). RNA quality was confirmed by electrophoresis on a $1 \%$ agarose gel.

\section{Determination of partial cDNA sequences for pro-VT and pro-IT}

To obtain partial cDNA sequences for pro-VT and pro-IT, first-strand cDNA was synthesized in a $20 \mu \mathrm{L}$ reverse transcription reaction by incubating $2 \mu \mathrm{g}$ of total RNA template $(3.48 \mu \mathrm{L})$ with $1.0 \mu \mathrm{L}$ dNTP (Promega, Madison, WI, USA), $0.5 \mu \mathrm{L}$ random primers, and $7.02 \mu \mathrm{L}$ of RNase-free $\mathrm{H}_{2} \mathrm{O}$ (Sigma) at $65^{\circ} \mathrm{C}$ for $5 \mathrm{~min}$. Subsequently, $4 \mu \mathrm{L}$ of $5 \mathrm{X}$ buffer and $1 \mu \mathrm{L}$ of SuperScript II Reverse Transcriptase enzyme (Invitrogen) were combined with $2 \mu \mathrm{L}$ of $0.1 \mathrm{M}$ DTT and $1 \mu \mathrm{L}$ of RNase inhibitor, and the mixture was incubated at room temperature for $10 \mathrm{~min}$ followed by $42^{\circ} \mathrm{C}$ for $50 \mathrm{~min}$ and $70^{\circ} \mathrm{C}$ for $15 \mathrm{~min}$.

PCR was performed using degenerate primers designed from consensus regions of cDNA sequences for pro-VT and pro-IT from other teleost fishes. Nested degenerate primers were designed to the cDNA sequences for pro-VT described 
previously from bluehead wrasse (Thalassoma bifasciatum, Genbank accession no. AY167033) and cichlid (A. burtoni, AF517935). The outer-nested primers were (forward) 5'-ATGCCTCACTCC(T/G)TG(T/A)TCCC-3' and (reverse) 5'-AGGG GGTGAGCAGGTAGTTCTC-3'. The inner nested primers used were (forward) 5'-TACATCCAGAA(C/T)TG(C/T)CCCCGAG-3' and (reverse) 5'-CCCTCAGA $(\mathrm{C} / \mathrm{T}) \mathrm{CCACAGG}(\mathrm{A} / \mathrm{G}) \mathrm{TCTC}-3^{\prime}$. Nested degenerate primers were designed to cDNA sequences for pro-IT from cichlid (GQ288466), Chinese wrasse (DQ073099), Parajulis poecilopterus (DQ073095), and European flounder (AB036518). The outer nested primers were (forward) 5'-AAATGACTGGA GAGCC(G/T)CTGT-3' and (reverse) 5'-GATGAGGAGAAG (C/T)G(C/T) GAC C-3'. The first set of inner nested primers used were (forward) 5'-TCCGTGTGCCT $(\mathrm{A} / \mathrm{T}) \mathrm{CT}(\mathrm{C} / \mathrm{T}) \mathrm{TT}(\mathrm{C} / \mathrm{T}) \mathrm{CT}(\mathrm{C} / \mathrm{T})(\mathrm{G} / \mathrm{C}) \mathrm{T}-3^{\prime}$ and (reverse) 5'-CAGATGCAG(C/G) AGCCTGA(A/G)GATGA-3', and the second inner nested set of primers were (forward) 5'-TG(C/T)TACATCTC(A/C/T)AACTGTCC(A/C/T)ATCGG-3' and (reverse) 5'-GGTC(A/G)CC(A/G)CCTTC(G/C)AATT-3'.

First-strand cDNA was amplified in $50 \mu \mathrm{L}$ PCR reactions containing $2 \mu \mathrm{L}$ of reverse-transcribed cDNA, $3.0 \mu \mathrm{L}$ of $\mathrm{MgCl}_{2}(25 \mathrm{mM}), 10 \mu \mathrm{L}$ of $10 \mathrm{X}$ Flexi buffer, $1.0 \mu \mathrm{L}$ of dNTP, $0.25 \mu \mathrm{L}$ of GoTaq polymerase (Promega), $1 \mu \mathrm{L}$ each of forward and reverse degenerate primers $(50 \mathrm{mM})$, and $31.75 \mu \mathrm{L}$ of RNase-free $\mathrm{H}_{2} \mathrm{O}$ under a thermal profile of $95^{\circ} \mathrm{C}$ for $2 \mathrm{~min}$, followed by 35 cycles of $95^{\circ} \mathrm{C}$ for $30 \mathrm{~s}, 49-51^{\circ} \mathrm{C}$ for $30 \mathrm{~s}$, and $72^{\circ} \mathrm{C}$ for $1 \mathrm{~min}$, and ending with $72^{\circ} \mathrm{C}$ for $10 \mathrm{~min}$. When electrophoresis of the PCR products on $1.2 \%$ agarose gels revealed bands of predicted size, the products were purified (QIAquick PCR Purification Kit, Qiagen, Inc., Valencia, CA) and sequenced (Macrogen, Inc., Korea). Partial cDNA sequences were obtained by aligning overlapping nucleotide sequences using Sequencher ${ }^{\mathrm{TM}} 4.8$ software (Gene Codes Corp., Ann Arbor, MI, USA) and analyzed against cDNA sequences from other vertebrates (ClustalW Method, Lasergene software; DNASTAR, Inc., Madison, WI, USA). Degenerate primer PCR and sequencing resulted in partial cDNA sequences for pro-VT (172 bp) and pro-IT (355 bp). The partial cDNA sequence for pro-IT is provided at GenBank accession no. GU441854.

\section{Sequencing of a full-length pro-VT cDNA}

Nested gene-specific primers to the partial cDNA sequence of pro-VT from Amargosa River pupfish were used to acquire the full-length pro-VT sequence by 5'- and 3'-rapid amplification of cDNA ends (BD SMART RACE cDNA Amplification Kit, Clontech Laboratories, Inc., Mountain View, CA, USA). Gene-specific primers for the 5'- and 3'-RACE reactions are as follows: 5'-RACE primer, 5'-TCCTCCTCACAGTGAGCTGATGCTGGTG-3'; and 3'-RACE primer, 5'-TGCTGTGGAGAGGGTCTGGGCTGC-3'. First-strand cDNA was amplified in a $50 \mu \mathrm{L}$ PCR reaction containing $2 \mu \mathrm{g}$ of reverse-transcribed cDNA from the combined brain and pituitary under a thermal profile of 5 cycles of $94^{\circ} \mathrm{C}$ for $30 \mathrm{~s}$, followed by $72^{\circ} \mathrm{C}$ for $2 \mathrm{~min}, 5$ cycles of $94^{\circ} \mathrm{C}$ for $30 \mathrm{~s}, 70^{\circ} \mathrm{C}$ for $30 \mathrm{~s}$, and $72^{\circ} \mathrm{C}$ for $2 \mathrm{~min}$, and then, 25 cycles of $94^{\circ} \mathrm{C}$ for $30 \mathrm{~s}, 68^{\circ} \mathrm{C}$ for $30 \mathrm{~s}$, and $72^{\circ} \mathrm{C}$ for $2 \mathrm{~min}$. The $5^{\prime}$ and $3^{\prime}$ RACE products were examined on $1.2 \%$ agarose gels; the cDNA was then purified (QIAquick PCR Purification Kit, Qiagen, Inc.) and sequenced. Full-length cDNA sequences were obtained using Sequencher ${ }^{\mathrm{TM}} 4.8$ software (Gene Codes 
Corp.) and analyzed against sequences for these transcripts from other vertebrates by the ClustalW Method.

To confirm the full-length pro-VT cDNA sequence, a nested set of primers was designed to the $5^{\prime}$ and $3^{\prime}$ untranslated regions (UTRs) of the cDNA. These primers are as follows: outer nested primers, (forward) 5'-ATCCAGACCAGCGGAGGA AAT-3' and (reverse) 5'-GCTGCAGGTCTTTAGGAGCAAG-3'; and inner nested primers, (forward) 5'-TCAGCTCACTGTGAGGAGGAGA-3' and (reverse) 5'-CAGCCCTCAGTGTTACAGCAGA-3'. Reverse-transcribed total RNA from the combined brain and pituitary was amplified in $50 \mu \mathrm{L}$ PCR reactions containing $2 \mu \mathrm{L}$ of cDNA template, $25 \mu \mathrm{L}$ of GoTaq polymerase master mix, $21 \mu \mathrm{L}$ of nuclease-free $\mathrm{H}_{2} \mathrm{O}$, and $1 \mu \mathrm{L}$ each of forward and reverse primers $(10 \mu \mathrm{M})$ under a profile of $95^{\circ} \mathrm{C}$ for $2 \mathrm{~min}$ followed by 35 cycles of $95^{\circ} \mathrm{C}$ for $30 \mathrm{~s}, 55^{\circ} \mathrm{C}$ for $30 \mathrm{~s}$, and $72^{\circ} \mathrm{C}$ for $90 \mathrm{~s}$, and then $72^{\circ} \mathrm{C}$ for $2 \mathrm{~min}$. The PCR products were examined on $1.2 \%$ agarose gels, and bands were excised, purified, and sequenced. The full-length cDNA for $C$. $n$. amargosae pro-VT is provided at GenBank accession no. GU138978.

\section{Real-time quantitative reverse-transcription $P C R$}

Total RNA was extracted from the whole brains of adult pupfish collected during the diel cycle sampling using Tri-Reagent (Molecular Research Center) with bromochloropropane as the phase separation reagent, and then DNase I treated (Invitrogen). Samples were then cleaned (RNeasy Kit, Qiagen) and quantified by spcctrophotomctry (260:280 ratios of 1.96-2.02; NanoDrop Tcchnologics). RNA quality was confirmed by electrophoresis on a $0.8 \%$ agarose gel.

Total RNA was reverse-transcribed (RT) in $25 \mu \mathrm{L}$ reactions containing $5.0 \mu \mathrm{L}$ of $5 \mathrm{X}$ buffer and $2.5 \mu \mathrm{L}$ of $0.1 \mathrm{M}$ DTT (Invitrogen), $1.25 \mu \mathrm{L}$ of dNTP (stock of $10 \mathrm{mM}$ each of dCTP, dGTP, dTTP, and dATP) and $0.426 \mu \mathrm{L}$ of random hexamer (500 ng $\mu \mathrm{L}^{-1}$ stock, Promega, Madison, WI, USA), $0.25 \mu \mathrm{L}$ of RNaseOUT inhibitor (40 $\mathrm{U}_{\mu} \mathrm{L}^{-1}$, Invitrogen), $0.313 \mu \mathrm{L}$ of SuperScript III polymerase $\left(200 \mathrm{U}_{\mu} \mathrm{L}^{-1}\right.$, Invitrogen), $10.28 \mu \mathrm{L}$ of $\mathrm{ddH}_{2} \mathrm{O}$ (nuclease-free water, Sigma, St. Louis, MO, USA) and $5.0 \mu \mathrm{L}$ of total RNA template $\left(15 \mathrm{ng} \mu \mathrm{L}^{-1}\right)$. All RT reactions were performed in 96-well plates on a thermal cycler (PTC-100, MJ Research) under a thermal profile of $25^{\circ} \mathrm{C}$ for $10 \mathrm{~min}, 50^{\circ} \mathrm{C}$ for $50 \mathrm{~min}$, and $85^{\circ} \mathrm{C}$ for $5 \mathrm{~min}$.

Primers and Taqman probes for real-time quantitative RT-PCR assays were designed to the cDNA sequences for pro-VT (Genbank accession no. GU138978) and pro-IT (GU441854) obtained above, as well as to cDNAs encoding V1a1 (Genbank accession no. GQ981412), V1a2 (GQ981413), V2 (GQ981414), and ITR (GQ981415) obtained previously from Amargosa pupfish (C. n. amargosae) (Lema 2010). Primers and probes for all quantitative RT-PCR reactions were synthesized by Integrated DNA Technologies (Coralville, IA, USA), and are given in Table 2. When possible, assays were designed to span an intro boundary.

Quantitative RT-PCR reactions were run in $25 \mu \mathrm{L}$ volumes with each reaction containing $12.5 \mu \mathrm{L}$ of Master Mix (ABI Universal MasterMix Reagent), $0.5 \mu \mathrm{L}$ of forward primer $(45 \mu \mathrm{M}), 0.5 \mu \mathrm{L}$ of reverse primer $(45 \mu \mathrm{M}), 0.5 \mu \mathrm{L}$ of probe $(10 \mu \mathrm{M})$, $8.0 \mu \mathrm{L}$ of $\mathrm{ddH}_{2} \mathrm{O}$ (nuclease-free water, Sigma) and $3.0 \mu \mathrm{L}$ of reverse-transcribed cDNA template. Reactions were run on an ABI 7500 Real-Time PCR System under a PCR thermal profile of $50^{\circ} \mathrm{C}$ for $2 \mathrm{~min}, 95^{\circ} \mathrm{C}$ for $10 \mathrm{~min}$, and then $40-45$ cycles 
Table 2. Nucleotide sequences for primers and Taqman probes used in quantitative real-time RT-PCR.

\begin{tabular}{|c|c|c|c|c|}
\hline Transcript & Primer or probe & Sequence $\left(5^{\prime}\right.$ to $\left.3^{\prime}\right)$ & $\begin{array}{l}\text { Amplicon } \\
\text { size (bp) }\end{array}$ & $\begin{array}{l}\% \text { PCR } \\
\text { efficiency }\end{array}$ \\
\hline pro-VT & $\begin{array}{l}\text { Forward primer } \\
\text { Probe } \\
\text { Reverse primer }\end{array}$ & $\begin{array}{l}\text { ATCAGAACCAGCAGCCATGCATCA } \\
\text { TGTGCGTCCTGGGACTCCTCGCCCTCT } \\
\text { AGTTCTGGATGTAGCAGGCGGA }\end{array}$ & 89 & 103.3 \\
\hline pro-IT & $\begin{array}{l}\text { Forward primer } \\
\text { Probe } \\
\text { Reverse primer }\end{array}$ & $\begin{array}{l}\text { TCGGCTCACTGCATAGAGGAGAACTA } \\
\text { ATGCAGAGAGCTGCACTGCAGATCAGAT } \\
\text { CACCTTCATACTGGCTGGTTTGGT }\end{array}$ & 184 & 99.5 \\
\hline V1a1 & $\begin{array}{l}\text { Forward primer } \\
\text { Probe } \\
\text { Reverse primer }\end{array}$ & $\begin{array}{l}\text { CTGCTCATCGGAAATCTCCTGCAA } \\
\text { ACCTAACGCAGAAGCAGGAGATTGGA } \\
\text { TGATTTCGATCTTGGCCACCTCCT }\end{array}$ & 155 & 102.6 \\
\hline V1a2 & $\begin{array}{l}\text { Forward primer } \\
\text { Probe } \\
\text { Reverse primer }\end{array}$ & $\begin{array}{l}\text { GGTGCAAATGTGGTCAGTGTGGGATA } \\
\text { TTGCCAGTCTCAACAGCTGCTGCAA } \\
\text { GAAGGTGGCCGCTAAAGATCATGT }\end{array}$ & 140 & 101.0 \\
\hline $\mathrm{V} 2$ & $\begin{array}{l}\text { Forward primer } \\
\text { Probe } \\
\text { Reverse primer }\end{array}$ & $\begin{array}{l}\text { CGCCCTCATCATTACCATCTGTCA } \\
\text { CCGCGAGATTCACAACAACATCTACCTG } \\
\text { AGCTCAGCCATCACTATCCTCTCT }\end{array}$ & 101 & 105.7 \\
\hline $\mathrm{EF} 1 \alpha$ & $\begin{array}{l}\text { Forward primer } \\
\text { Probe } \\
\text { Reverse primer }\end{array}$ & $\begin{array}{l}\text { TACAAGTGCGGAGGAATCGACAAG } \\
\text { TGGACAAACTGAAGGCCGAGCGTGA } \\
\text { GGTCTCAAACTTCCACAGAGCGAT }\end{array}$ & 162 & 103.1 \\
\hline
\end{tabular}

of $95^{\circ} \mathrm{C}$ for $15 \mathrm{~s}$ and $60^{\circ} \mathrm{C}$ for $1 \mathrm{~min}$. All samples for each gene were run on a single 96-well plate. Serial dilution of a single total RNA from the experiment was used as a standard curve reference, and correlation coefficients $\left(r^{2}\right)$ of the standard curves were always $>0.97$. All standard curve samples were run in triplicate. PCR efficiencies for each gene were calculated from the standard curves using the following formula: $E=-1+10^{(-1 / \text { slope) }}$ (Rasmussen 2000), and are presented in Table 2. Each run also included duplicate samples lacking cDNA template to further check for DNA contamination during RNA preparation. As an internal reaction control for each gene of interest, we quantified transcript levels of elongation factor $1 \alpha$ (EF $1 \alpha$; Genbank accession no. EU906930). Transcript levels of EF1 $\alpha$ were similar across all treatments $\left(F_{5,64}=1.39, p=0.25\right)$ and sexes $\left(F_{1,64}=0.44, p=0.51\right)$. Transcript levels for genes of interest were calculated using the serially diluted standard curve and were expressed relative to EF $1 \alpha$ mRNA levels in the given sample. The relative level of gene transcript was then calculated by dividing the above values by the mean of the male control group (Pfaff 2001). This calculation provides a clear representation of the relative changes in abundance of each transcript across sampling times, and illustrates relative mRNA level comparisons between sexes.

\section{Statistical analyses}

To test whether pupfish behavior varied over the diel cycle, behaviors were compared among sampling times using one-factor ANOVA models. When the 
ANOVA model revealed a significant effect of time, multiple pairwise comparisons were made among all sampling times using Tukey HSD tests. Data were square-root transformed prior to analysis when behavioral data failed to conform to the assumptions of normality. Spawning event data was not statistically compared, given that spawning was not observed in $83.3 \%$ of the 2 min behavioral observations (thereby resulting in a value of " 0 " for spawning frequency during each of those observation periods).

Transcript abundance data for pro-VT, pro-IT, and the VT/IT receptors were analyzed by three-factor ANCOVA models with "sex" and "collection time" as main effect factors, and "body mass" as a covariate. All interactions between these factors were also included in the models. Body size was used as a covariate because body mass showed a marginally significant difference among sampling times for male $\left(F_{5,35}=2.32, p=0.06\right)$, but not female $\left(F_{5,28}=1.89, p=0.12\right)$, pupfish. When a significant effect of "collection time" was found, gene expression values for each time were compared using Tukey HSD tests. Subsequent linear regressions were conducted to test for relationships between transcript abundance and "body mass" for each sex separately.

\section{Results}

\section{Diel variation in pupfish behavior}

The frequencies of feeding, aggression, and courtship behaviors of pupfish varied diurnally (Figure 2). Pupfish foraging rates fluctuated during the day-night cycle $\left(F_{3,23}=7.017, p=0.0021\right)$, with greatest feeding activity in morning (08:00 h), reduced feeding at midday $(12: 00$ and 15:00 h), and moderately elevated feeding in the evening (19:00 h) (Figure 2a). Pupfish were found to be inactive at night, instead losing the blue body coloration typical of males during the day and lying stationary on the substrate during the nighttime hours. Feeding was not observed in any of the nighttime observations.

The frequency of aggression also varied from day to night, with the highest occurrence of aggressive charges $\left(F_{3,23}=7.878, p=0.0012\right)$ and nips $\left(F_{3,23}=11.885\right.$, $p<0.0001)$ during midday (12:00 and 15:00 h; Figure 2b). Reproductive behaviors showed diurnal variation as well with increased courtship sidling $\left(F_{3,23}=7.670\right.$, $p=0.0013)$ and spawning activity during the afternoon (15:00 and 19:00 h; Figure 2c). This increased reproductive activity was lagged a few hours behind the elevated aggression seen in the population at midday. Again, since pupfish became inactive at night, no instances of aggressive or reproductive behaviors were observed during nighttime hours. While the overall density of pupfish in each quadrat was lower during dark hours (04:00 and 23:00 h) than during light hours $(08: 00,12: 00$, 15:00, and $\left.19: 00 \mathrm{~h} ; F_{5,30}=4.71, p=0.003\right)$, the absence of significant changes in density during daylight hours $\left(F_{3,23}=0.19, p=0.90\right)$ suggests that the diurnal changes in behavior observed here are not due to variation in fish density.

Analysis of the species involved in each agonistic interaction revealed that pupfish directed many of their aggressive behaviors toward non-native mosquitofish (G. affinis), rather than toward other pupfish (Table 3). Averaged over the entire $24 \mathrm{~h}$ observation period, pupfish directed $45.9 \%$ of aggressive charges and $65.8 \%$ of aggressive nips toward this non-native fish. 


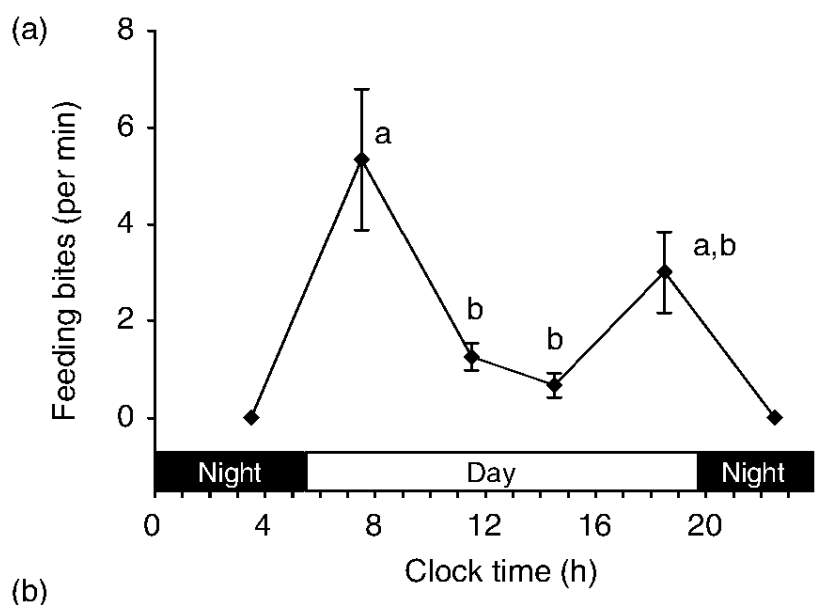

(b)

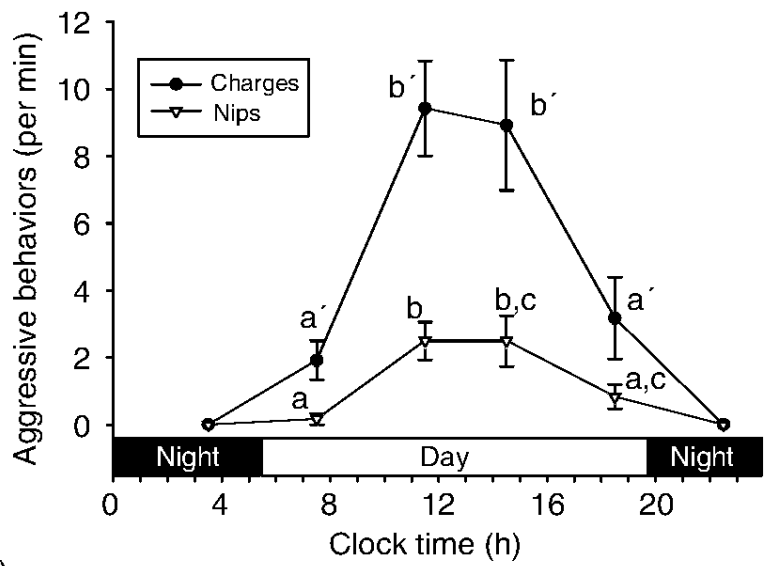

(c)

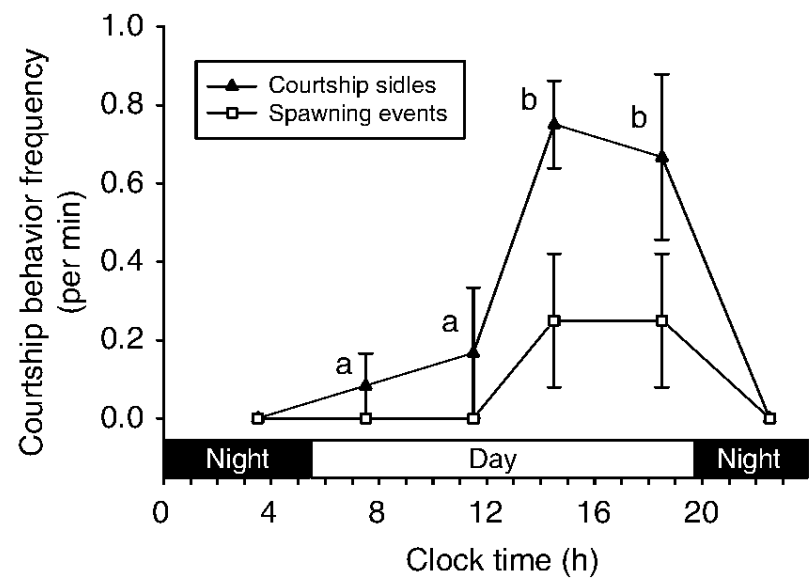

Figure 2. Pupfish behavior varied significantly in the marsh habitat over the $24 \mathrm{~h}$ study period. The frequency of feeding bites (a) showed diel variation with highest feeding in the morning $(07: 40 \mathrm{~h})$ and reduced feeding midday. Aggressive charges and nips (b) varied across the day-night cycle, with the highest rates of aggression during the midday (11:40 and 14:40 h). Courtship behavior and spawning activity (c) also varied with greatest frequency of these behaviors in late afternoon (14:40 and 18:40 h). Letters indicate statistically similar data points (Tukey HSD tests) within each behavior. Spawning behavior was not analyzed statistically since it only occurred during the 14:40 and 18:40 h sampling times. Data are plotted as mean \pm SEM. 
Table 3. Mean \pm SEM frequency (per $2 \mathrm{~min}$ ) of pupfish aggressive behaviors directed toward pupfish or non-native mosquitofish (G. affinis).

\begin{tabular}{lccc}
\hline & & \multicolumn{2}{c}{ Aggressive behaviors (per 2 min) } \\
\cline { 3 - 4 } Time $(\mathrm{h})$ & Behavior & Pupfish & Mosquitofish \\
\hline $07: 30$ & Charges & $2.50 \pm 0.56$ & $1.33 \pm 0.80$ \\
& Nips & $0.00 \pm 0.00$ & $0.33 \pm 0.33$ \\
$11: 30$ & Charges & $9.00 \pm 1.55$ & $9.67 \pm 1.73$ \\
& Nips & $2.50 \pm 0.76$ & $2.50 \pm 1.18$ \\
$14: 30$ & Charges & $11.17 \pm 3.90$ & $7.00 \pm 2.00$ \\
& Nips & $0.33 \pm 0.21$ & $4.67 \pm 1.58$ \\
$18: 30$ & Charges & $2.83 \pm 1.08$ & $3.50 \pm 1.41$ \\
& Nips & $0.83 \pm 0.40$ & $0.83 \pm 0.48$ \\
\hline
\end{tabular}

\section{Diurnal variation in neural pro-VT and pro-IT transcript abundance}

Neural pro-VT mRNA levels showed diurnal variation in both males and females $\left(F_{5,64}=4.18, p=0.003\right)$, with reduced transcript abundance during the day $(12: 00 \mathrm{~h})$ and elevated transcripts at night (Figure 3). Similar diurnal patterns of pro-VT mRNA variation were observed in both male and female pupfish $\left(F_{1,64}=3.19\right.$, $p=0.080$ ). Pro-VT transcript abundance also showed a positive relationship with body size in adult female pupfish (Figure 4a), but not in adult male pupfish (Figure 4b). Neural pro-IT levels were stable across the $24 \mathrm{~h}$ sampling period $\left(F_{5,64}=1.78, p=0.133\right)$ and showed no significant expression difference between the sexes $\left(F_{5,64}=0.63, p=0.429\right.$ : Figure 3$)$. Pro-IT mRNA levels did, however, show a positive relationship with body mass in both adult female and male pupfish (Figure $4 \mathrm{c}$ and d).

\section{Diurnal changes in mRNAs encoding pupfish vasotocin and ITRs}

Transcripts encoding the pupfish vasotocin receptors V1a1, V1a2, and V2 were also examined in the brain for evidence of changes over the diel cycle. V1al transcript abundance was similar between males and females $\left(F_{1,64}=0.08, p=0.776\right)$, and showed no change over the diel cycle in either $\operatorname{sex}\left(F_{5,64}=0.58, p=0.715\right.$; Figure $5 \mathrm{a}$ and $\mathrm{b}$ ). V1a2 receptor mRNA levels, in contrast, varied diurnally in sex-specific patterns (collection time $\times$ sex interaction, $F_{5,64}=3.43, p=0.008$ ) . In females, V1a2 mRNA levels peaked in abundance at 08:00 h, and declined through the day until early morning (Figure 5c). In males, however, V1a2 mRNA levels were greatest in the late afternoon and evening (15:00 and 19:00 h), and declined quickly after sunset to lowest levels at 23:00 h (Figure 5d). V2 receptor transcript also varied over the $24 \mathrm{~h}$ sampling period $\left(F_{5,64}=4.30, p=0.002\right)$, with reduced transcript abundance in the afternoon (15:00 h; Figure 5e and $\mathrm{f}$. The general pattern of V2 transcript variation was similar for males and females $\left(F_{1,64}=0.50\right.$, $p=0.774$ ), even though the temporal changes observed for female pupfish were not as significant as for males when calculated in Tukey HSD pairwise comparisons (Figure 5e and f). Relative values of V1a1, V1a2, and V2 mRNA levels in the brain appeared similar to those seen using RT-PCR (Lema 2010), with V1a1 and V1a2 transcripts expressed at considerably higher levels than V2 transcripts. For each 
(a)

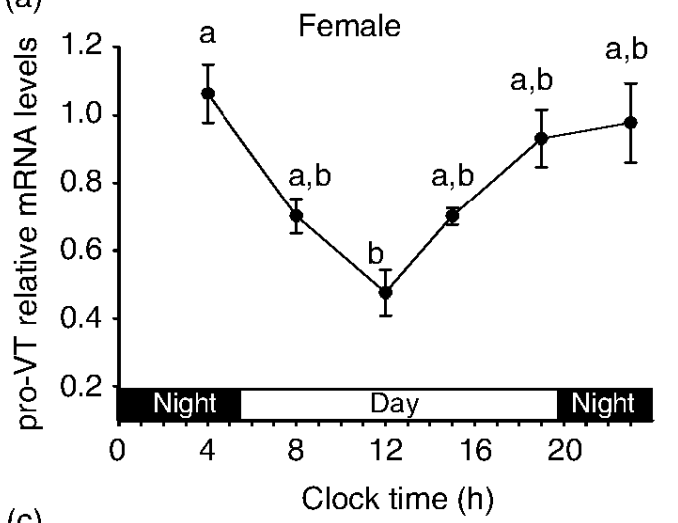

(c)

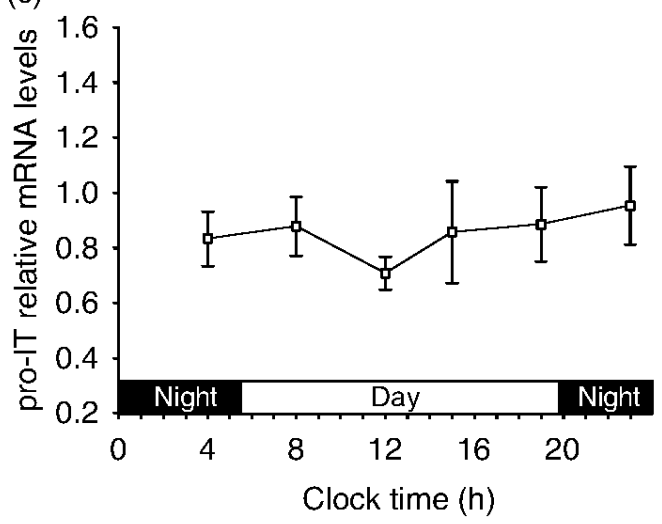

(b)

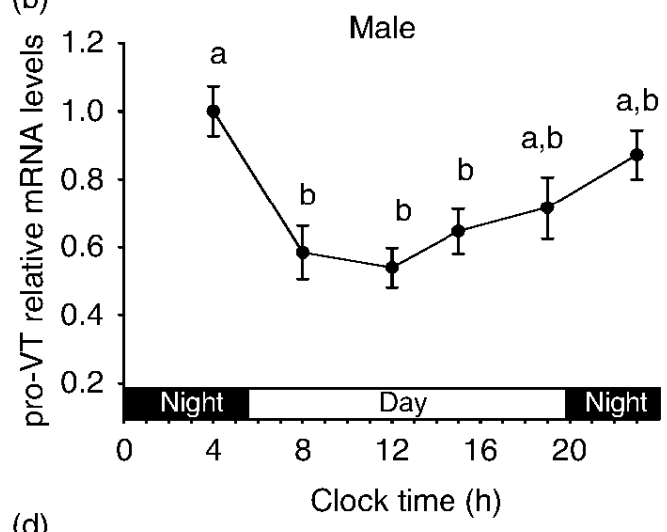

(d)

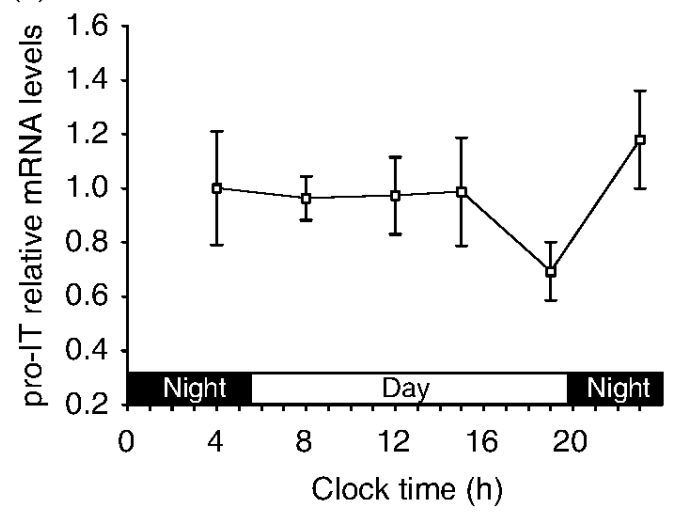

Figure 3. Neural pro-VT mRNA levels varied in both female (a) and male (b) pupfish over the diel cycle. Neural pro-IT mRNAs, however, did not vary in either females (c) or males (d). Letters indicate statistically similar values (Tukey HSD tests) of pro-VT mRNA levels within each sex. Data are plotted as mean \pm SEM.

transcript, however, mRNA expression was plotted at levels relative to males from the 04:00 h sampling time, so plotted data does not reflect the relative expression differences between transcripts. Body mass did not affect the mRNA levels of any VT receptor.

Transcripts for the ITR also showed diurnal variation in both sexes of pupfish $\left(F_{5,64}=7.47, p<0.0001\right)$, with highest transcript abundance during early morning $(04: 00 \mathrm{~h})$ and a gradual decline in transcripts throughout the day until reaching a low at 15:00 h (Figure 6). This pattern of ITR mRNA variation was similar between the sexes $\left(F_{1,64}=1.06, p=0.306\right)$.

\section{Discussion}

\section{Diurnal changes in pupfish behavior}

Amargosa pupfish, and other pupfish species, display a breeding system that ranges from territoriality to a dominance hierarchy depending on the density and sex ratio of fish in the habitat (Kodric-Brown 1981). Male pupfish are highly pugnacious as they establish and defend reproductive territories over the substrate, while females spend the majority of their time feeding and usually only approach these territorial males to spawn (Kodric-Brown 1978; Leiser and Itzkowitz 2003). Overall, however, 
(a)

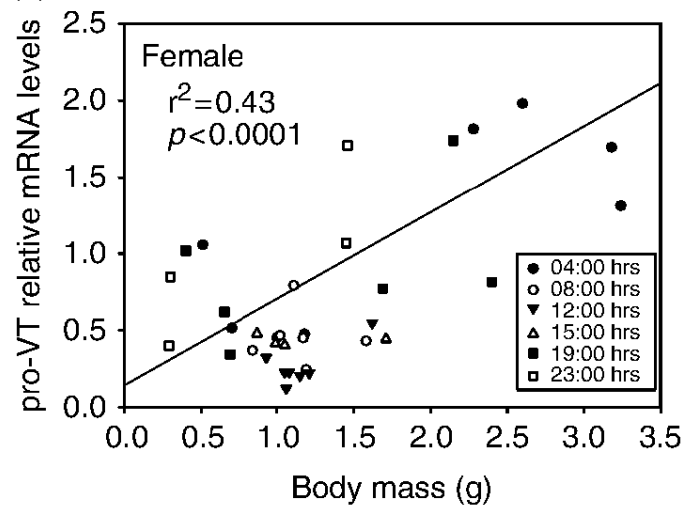

(c)

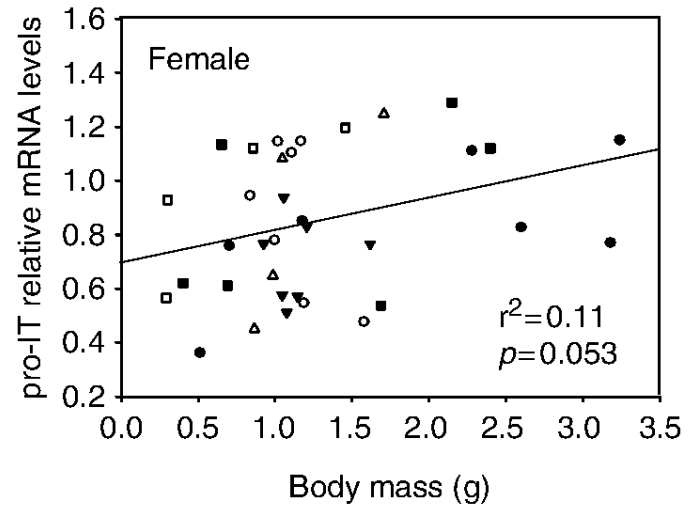

(b)

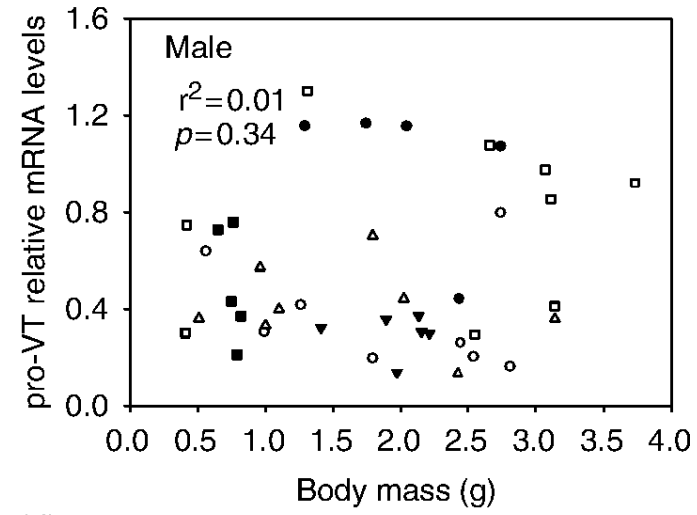

(d)

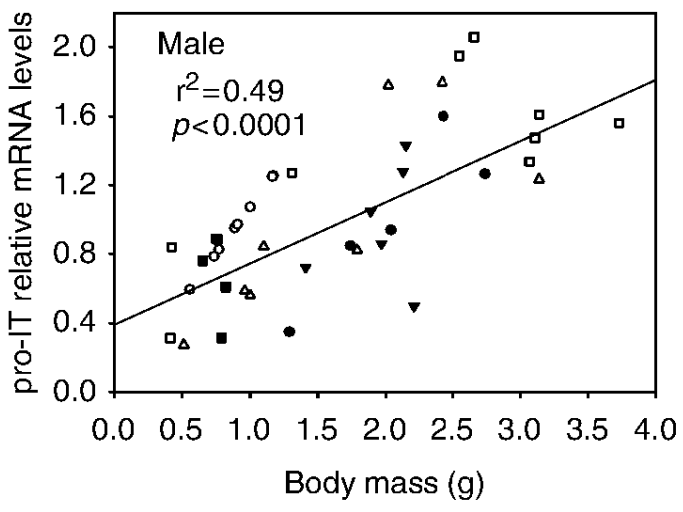

Figure 4. Neural pro-VT mRNA levels showed a positive relationship with body size in female (a) but not male (b) pupfish. Pro-IT mRNA levels increased with body size in both females (c) and males (d).

the breeding system of pupfish is dynamic, and social structure in the Amargosa pupfish has been shown to vary both among allopatric populations and seasonally within a single habitat (Soltz 1974; Kodric-Brown 1981). While several studies have examined how the structure and size of a habitat influences variation in pupfish behavior (Kodric-Brown 1981), we are unaware of any published accounts of how the behavior of Amargosa pupfish varies diurnally within a habitat. Here, observation of diel patterns of behavior in Amargosa pupfish revealed most frequent feeding in morning and evening (08:00 and 19:00 h), frequent aggression in early afternoon (12:00-15:00 h), and courtship and spawning most common in late afternoon (15:00-19:00 h). Although the number of sampling times prohibits assessment of statistical correlations between behavior and physical variables, the frequency of aggressive behaviors was highest when the light intensity was greatest (Figures 1 and 2b), while the frequency of courtship and spawning showed a lag relative to aggression, and instead was greatest when water temperatures were highest in the habitat (Figures 1 and 2c). At night (04:00 and 23:00 h), pupfish were observed to be inactive and remained stationary on the substrate, as has been observed qualitatively for other pupfish species in the wild (e.g., Cyprinodon macularius; Barlow 1958). While there is little data from other pupfishes with which to compare our diurnal observations of $C . n$. amargosae behavior, the bimodal pattern of foraging with feeding elevated in early morning and late afternoon, coupled with increased spawning activity between these times, corresponds well 

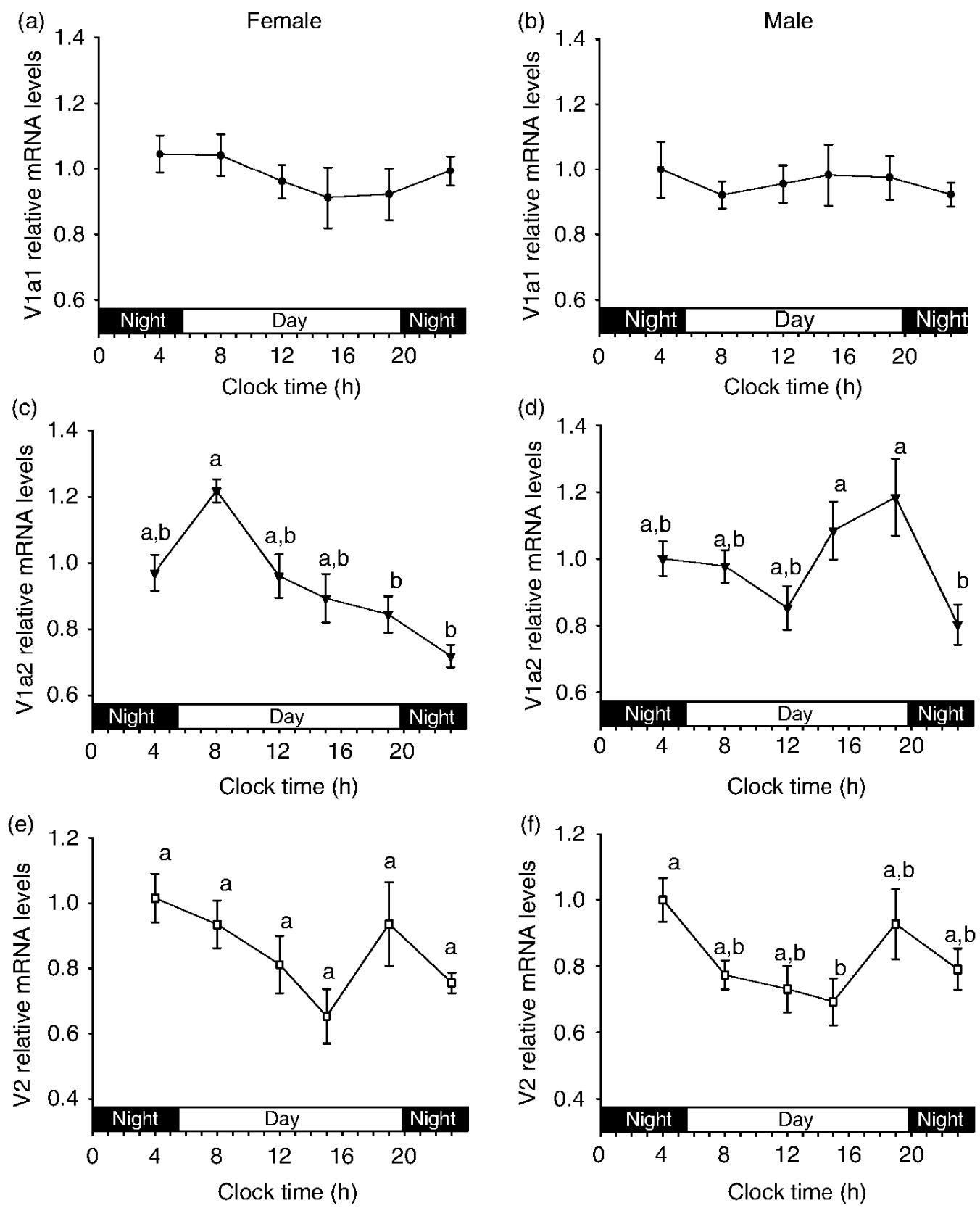

Figure 5. Diurnal patterns of transcript abundance for the V1a1 (a,b), V1a2 (c,d), and V2 $(e, f)$ receptors for vasotocin shown by sex. V1a1 receptor mRNAs did not vary diurnally in either sex, while V1a2 receptor mRNAs showed a distinct sex difference in patterns of change over the diel cycle. V2 receptor transcript abundance varied from day to night, and followed a similar pattern of variation in both sexes. Letters indicate statistically similar values (Tukey HSD tests) within each sex. Data are plotted as mean \pm SEM.

to the daily patterns of feeding and spawning observed in the closely related Devil's Hole pupfish (Cyprinodon diabolis) in its natural habitat of Devil's Hole (James 1969). In this species, feeding activity was most common in early morning and late afternoon, while spawning and chasing - although rare - were found to be more frequent closer to midday (James 1969). 

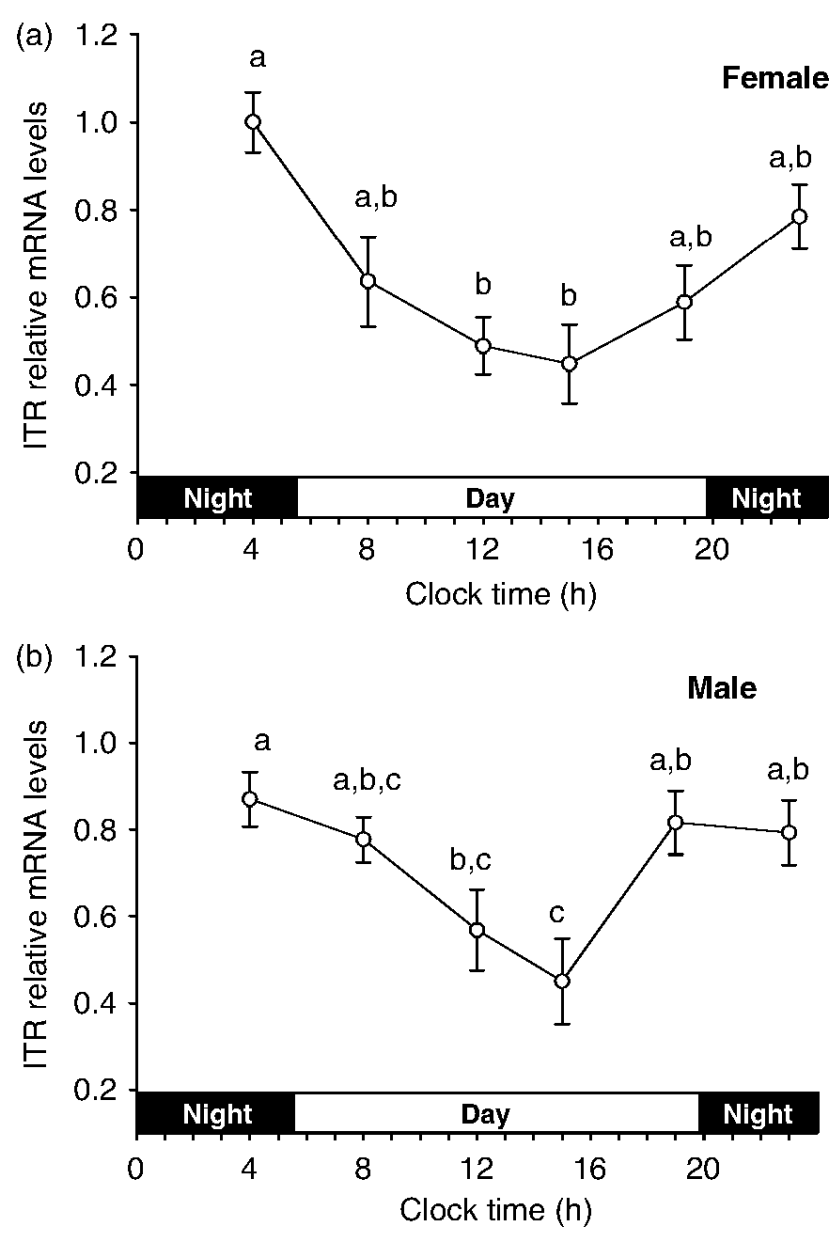

Figure 6. Diurnal variation in transcript abundance for ITR in the brain of female (a) and male (b) Amargosa pupfish. Letters indicate statistically similar values (Tukey HSD tests) within each sex. Data are plotted as mean \pm SEM.

In previous work with Amargosa pupfish and other closely related pupfishes, behavioral variation on a daily or seasonal basis was suggested to be influenced by changes in light and temperature (e.g., Barlow 1958; Soltz 1974). Pupfish are generally inactive at night regardless of water temperature, indicating a strong influence of light intensity on behavior (Barlow 1958; James 1969; Lema, unpublished observations). Seasonal changes in pupfish reproduction and associated aggressive behaviors have also, however, been linked to water temperature, with aggression and spawning behaviors by pupfish most frequent at temperatures ranging from $20^{\circ} \mathrm{C}$ to $35^{\circ} \mathrm{C}$ (Raney et al. 1953; Barlow 1958; Soltz 1974). Complicating direct relationships between water temperature and behavior in the wild, pupfish often shift their behavior and patterns of habitat use with the dramatic changes in temperature that many of their habitats experience (sometimes $>25^{\circ} \mathrm{C}$ between day and night, Lema, unpublished observations; Feldmeth 1981; Lema 2006). For instance, observations of the pupfish C. macularius in shore pools of the Salton Sea, California, revealed diel shifts in movement between shallow habitats and deeper pools in accordance with diurnal changes in water temperature (Barlow 1958). These pupfish also exhibited diurnal changes in foraging, with feeding behaviors most common at temperatures below $36^{\circ} \mathrm{C}$. When temperatures rose 
above $36^{\circ} \mathrm{C}, \mathrm{C}$. macularius pupfish became inactive and lay stationary on the substrate (Barlow 1958). Although no study has attempted to separate the influences of temperature and light intensity on pupfish behavior, and these environmental factors are often linked in field studies of thermally variable habitats, it is clear from our findings here - and from the results of previous studies - that both light intensity and temperature are key regulators of pupfish behavior in the wild.

Our quantitative observations of Amargosa pupfish behavior revealed that pupfish directed aggression not only toward other pupfish, but also toward non-native mosquitofish ( $G$. affinis) and, in a few instances, even aquatic invertebrates. Overall, $45.9 \%$ of aggressive charges and $65.8 \%$ of aggressive nips by pupfish were directed toward mosquitofish. Mosquitofish are an invading species in the Amargosa River and its associated marshes (i.e., Scoppettone et al. 2005), and the presence of mosquitofish has been linked to declines in the abundance of native fishes, including several federally endangered species of pupfish (Schoenherr 1981). Using a combination of field and laboratory studies with Cyprindon variegatus pupfish, Itzkowitz (1974) observed that territorial males will chase heterospecifics out of their territories, but appear to preferentially direct aggressive behaviors toward conspecifics (but see Leiser 2003). Under controlled laboratory conditions, territorial intrusions by both conspecific and heterospecific fish were found to influence $C$. variegatus reproduction by reducing the number of spawns by a consorting pair, likely via direct disruption of the courtship sequence (Itzkowitz 1974). However, recent evidence from experimental behavioral tests of C. variegates also suggests that the impact of heterospecific territorial intruders on the frequency of pupfish spawning may be greater than that of conspecific intruders (Leiser 2003), implying that non-native species may have disproportional impacts on the reproductive behaviors of pupfish. Our finding here that Amargosa pupfish directed $45-65 \%$ of their aggressive behaviors towards non-native mosquitofish points to a need for future studies on how non-native species impact energy expenditure and rates of reproduction of imperiled pupfishes in the Death Valley region and other areas of the American Southwest.

\section{Diel variation in the VT-IT systems and potential associations with behavior}

The results presented here establish diurnal patterns of abundance for mRNAs encoding the neuropeptide VT and its three receptors (V1a1, V1a2 and V2), as well as for IT and its receptor, in the brain of adult Amargosa pupfish. It was only recently discovered that the Amargosa pupfish evolved three distinct VT receptor genes encoding three putative receptors (Lema 2010), making this species the first teleost fish identified with multiple receptors for VT. At present, however, almost nothing is known about the functional differentiation or expressional regulation of these VT receptors. Here, we found that gene transcripts encoding two of the VT receptors - the $\mathrm{V} 1 \mathrm{a} 2$ and $\mathrm{V} 2$ receptors - exhibited diurnal changes in abundance in the brain, while transcripts for the third VT receptor - V1a1 - did not show diurnal variation. Similarly, transcripts for the IT receptor also varied diurnally. What is more, our results revealed that the diurnal pattern of variation in V1a2 receptor mRNA levels differed between male and female pupfish. To our knowledge, this is the first study examining diurnal variation in mRNAs encoding VT receptors, or the IT receptor, in the brain of a teleost fish. 
Previous work with adult Amargosa pupfish has shown brain VT immunoreactivity (VT-ir) to be predominantly localized to the parvocellular and magnocellular neurons of the POA of the hypothalamus (Lema and Nevitt 2004b). The size of these VT-ir neurons in both the parvoceullular and magnocellular regions was found to be greater in male than in female Amargosa pupfish, while the number of these VT-ir neurons and the overall distribution pattern of VT-ir somata and fibers were similar between the sexes (Lema and Nevitt 2004b). The distribution pattern of VT-ir in the pupfish brain is similar to the distributions of VT-ir and pro-VT mRNA (as detected by in situ hybridization) observed in other fish species (Goossens et al. 1977; Van Den Dungen et al. 1982; Foran and Bass 1998; Godwin et al. 2000; Duarte et al. 2001; Miranda et al. 2003; reviewed by Goodson and Bass 2001), indicating that the majority of pro-VT mRNA signal detected in the pupfish brains examined here likely comes from the hypothalamus. VT from the hypothalamic POA is secreted via the neurohypophysis into systemic circulation to regulate physiological processes including hydromineral balance and vasculature pressure, as well as into the pituitary gland to regulate stress responses via the HPI axis (Warne 2002; Balment et al. 2006). VT from the POA also appears to be released locally within the brain to modulate behavior (Goodson and Bass 2001).

In this study, we found that pro-VT transcript abundance within the brain of wild Amargosa pupfish varied diurnally, with pro-VT mRNAs declining after the beginning of the light photoperiod to lowest levels at 12:00 h, and increasing in the afternoon to reach maximum levels during the dark phase at 04:00 h. Male and female pupfish showed similar diurnal patterns in pro-VT transcript abundance. Pro-IT transcripts, in contrast, were stable in abundance over day-night in both males and females. Whole brain pro-VT mRNAs in females and pro-IT mRNAs in both sexes also showed positive relationships with fish size, while pro-VT transcripts in males did not. Why pro-VT mRNAs were not related to body size in males is not clear, but given that hypothalamic pro-VT transcripts have been previously shown to be associated with social status in other fishes (Greenwood et al. 2008), it is possible that individual variation in the social status of the male pupfish (i.e. territorial or non-territorial) might have masked any direct relationship with the body size alone.

While relationships between pro-VT mRNA levels and social status in pupfish remain to be examined, diurnal changes in hypothalamic, pituitary gland or plasma VT peptide have been observed previously in several fishes. For instance, plasma VT peptide showed diurnal variation in flounder (Platichthys flesus) under a 12L:12D photoperiod, with VT levels being the greatest during the light phase (Kulczykowska et al. 2001). In rainbow trout (Oncorhynchus mykiss) held under a 8L:16D photoperiod, plasma levels of VT - but not IT - were also found to vary diurnally (Kulczykowska and Stolarski 1996). Diurnal changes in VT peptide, however, do not appear to be limited to VT in circulation, as VT content in the hypothalamus - but not the telencephalon - varied from day to night in goldfish (Carassius auratus) maintained under a 12L:12D photoperiod (Hontela and Lederis 1985). Similarly, whole brain VT content varied in sea bream (Sparus aurata) maintained under constant light conditions (Gozdowska et al. 2006). Seemingly, changes in VT peptide levels should be preceded by changes in pro-VT transcript abundance. However, tests of this relationship are sparse, and only a few studies have examined diurnal variation in VT or IT transcript abundance in the fish brain. In one study, examination of pre-spawning adult chum salmon (Oncorhynchus keta) revealed that 
pro-VT and pro-IT mRNA levels were constant in the hypothalamus over a diel cycle (Saito et al. 2004). Gilchriest et al. (1998), however, found that pro-VT mRNAs showed diurnal variation in abundance in parvocellular, but not magnocellular, neurons in the POA of rainbow trout. In these captively raised fish, parvocellular pro-VT transcripts increased in the morning $(8: 00-14: 00 \mathrm{~h})$ to reach maximum levels in late afternoon (14:00-22:00 h), and declined after the onset of dark $(22: 00 \mathrm{~h})$, a pattern opposite to that seen here in Amargosa pupfish. This diurnal cycle of parvocellular pro-VT transcript abundance in trout did not translate into changes in either hypothalamic or pituitary VT peptide content, both of which remained at constant levels over the $24 \mathrm{~h}$ cycle (Gilchriest et al. 1998). Rather, parvocellular pro-VT transcript abundance followed a diurnal pattern of variation inverse to that of plasma cortisol in the trout (Gilchriest et al. 1998), suggesting that parvocellular VT might regulate diurnal changes in HPI axis activity or, alternatively, that cortisol might exert negative feedback control on hypothalamic pro-VT gene transcription. VT has been shown to act synergistically with corticotrophin-releasing factor (CRF) to regulate hypothalamic adrenocorticotropin (ACTH) release in fish (Baker et al. 1996), but we are unaware of any experimental evidence that cortisol regulates hypothalamic pro-VT transcription in teleosts.

Whereas studies of diurnal variation in VT and IT in fish remain limited, evidence from mammals suggests that vasopressin (VP) - VT's mammalian homolog - plays a key role in regulating circadian and seasonal timekeeping (Caldwell et al. 2008a). In the diurnal grass rat (Arvicanthis niloticus), sexually mature males and females show similar patterns of diel change in pro-vasopressin (pro-VP) mRNA levels in the suprachiasmatic nucleus (SCN) - the main circadian pacemaker nucleus in mammals - with pro-VP mRNA levels peaking at 05:00-09:00 $\mathrm{h}$ and lowest at 21:00 h (Mahoney et al. 2009). Similar diurnal cycles of pro-VP transcript abundance have been documented in the SCN of other rodents (Uhl and Reppert 1986; Tominaga et al. 1992; Yambe et al. 2002; Kalamatianos et al. 2004). Diurnal cycles of VP production in the SCN appear to regulate SCN neuronal activity, as VP and VT both increase the firing activity of SCN neurons while V1 receptor antagonists depress activity (Mihai et al. 1994). V1a knockout mice show a reduced day-night rhythm of locomotor activity, further supporting the hypothesis that the timekeeping action of VP in the mammalian SCN is mediated by the V1a receptor (Li et al. 2009). In several rodents, transcripts for the $\mathrm{V} 1 \mathrm{a}$ receptor - but not for the $\mathrm{V} 1 \mathrm{~b}$ receptor also show diurnal rhythmicity in the SCN, with peak mRNA levels occurring around 16:00-22:00 h (Duncan et al. 1995; Kalamatianos et al. 2004; Li et al. 2009). Several mammalian brain regions besides the SCN (e.g., medial POA, bed nucleus of the stria terminalis) also exhibit photoperiodic regulation of $\mathrm{V} 1 \mathrm{a}$ receptor expression (Caldwell and Albers 2004a), and changes in V1a expression in these other regions have been linked to photoperiod-dependent effects of VP on behavior. For example, in Syrian hamsters, injection of VP into the anterior hypothalamus increases aggression (Ferris et al. 1997), although the effects of VP differ with photoperiodinduced variation in V1a receptor density (Ferris and Potegal 1988; Caldwell and Albers 2004b).

Comparable experiments that link neural VT receptor expression to behavior remain to be conducted in teleost fishes, and only recently were three distinct VT receptor cDNAs (V1a1, V1a2 and V2) identified in fish (Lema 2010), so little is known about the roles these three receptors might play in fish physiology and behavior. Phylogenetic examination of the deduced amino acid sequences 
of the $\mathrm{V} 1 \mathrm{a} 1$ and $\mathrm{V} 1 \mathrm{a} 2$ receptors indicates that both receptors belong to a clade of VP-VT receptors that includes the mammalian V1a-type receptors (Lema 2010). Given the high structural homology of the V1a1 and V1a2 receptors, these two VT receptor genes likely evolved from a gene duplication event during the evolutionary diversification of teleost fishes. In both male and female Amargosa pupfish, V1a1 and V1a2 mRNAs are both expressed at high levels in the midbrain and cerebellum (Lema 2010), and while the functional expression of these two receptor cDNAs has not been shown, the deduced amino acid sequences of the V1a1 and V1a2 receptors show conservation at several amino acid residues identified as important for receptor protein binding to VT.

While little is known about the functions of these pupfish VT receptors at present, results from this study may help to shed light on the receptors' functions by providing evidence that the pupfish brain shows diurnal variation in transcripts encoding the V1a2, but not V1a1, receptor. Specifically, we found that day-night patterns of V1a2 transcript abundance in the brain differed between the sexes, with peak V1a2 transcript abundance occurring at 08:00 h in males (Figure 5c), but at 19:00 h in females (Figure 5d). Phylogenetically, the V1a2 receptor in pupfish is homologous to VT receptors identified previously from other teleost fishes (Lema 2010). While no other studies have examined diurnal changes in VT or IT receptor expression in fish, recent work suggests that transcript abundance for a teleost V1a-type receptor increases in the hindbrain of goldfish ( $C$. auratus) during the breeding season (Walton et al. 2010), which suggests either photoperiodic regulation seasonally or regulation by changes in gonadal steroid production. Sex steroid regulation of neural VT receptor expression has not yet been explored in fish, but gonadal steroids do appear to regulate $\mathrm{V} 1 \mathrm{a}$ receptor binding in the brain of rodents (Delville et al. 1996; Young et al. 2000; Caldwell et al. 2008b). Castration has also been shown to have photoperiod-dependent effects on hypothalamic V1a receptor binding in the Syrian hamster and alter VP-regulated male behaviors such as flank marking (Caldwell et al. 2008b). Given this evidence from mammals and the sex differences in pupfish V1a2 receptor mRNA levels observed over a diel cycle here, it seems plausible that VT's sex-specific effects on behavior (e.g., aggression, courtship) (Goodson and Bass 2000; Lema and Nevitt 2004b; Thompson and Walton 2004) are mediated via the V1a2 receptor. Clearly, future studies are needed to explore the role of this $\mathrm{V} 1 \mathrm{a} 2$ receptor in behavior and reproduction, and these studies should include experiments designed to test for influences of sex steroids on VT receptor gene transcription in the piscine brain. It is important to note, however, that $\mathrm{V}$ la receptor binding in the mammalian brain has also been demonstrated to be regulated by glucocorticoids (Patchev and Almeida 1995; Watters et al. 1996), and diurnal differences in brain V1a2 mRNA levels between the sexes could alternatively be explained by sex differences in social stresses (e.g., aggression). VT has been shown to stimulate pituitary ACTH release in fish (Baker et al. 1996), and acute stressor exposure alters pro-VT mRNA levels in the hypothalamus in trout (Gilchriest et al. 2000). Such evidence provides support that glucocorticoids may feedback to regulate the hypothalamic VT system, although future studies are needed to examine whether any such feedback affects gene expression patterns in the brain for the $\mathrm{V} 1 \mathrm{a} 2$ receptor, or for any of the piscine VT receptors.

In addition to the diurnal changes in V1a2 receptor transcripts, mRNAs encoding the V2 and ITR receptors also varied diurnally in the brain of Amargosa pupfish. Transcripts for the $\mathrm{V} 2$ receptor showed a diel pattern in expression with 
declining levels throughout the day, and peak abundance prior to the onset of dark (Figure 5e and f). This pattern was similar between males and females. Likewise, mRNAs for the IT receptor showed similar patterns of change in males and females with peak transcript abundance occurring during dark phase (04:00 h), and lowest mRNA levels occurring at 15:00 h (Figure 6). The expressional distributions and functions of these receptors in the fish brain remain largely unknown. The Amargosa pupfish V2 receptor belongs to a clade of VT-VP receptors that includes all mammalian and amphibian (but not avian) V2-type receptors (Lema 2010), but given that this pupfish V2 receptor was the first V2-type receptor cDNA identified in teleost fishes, just about nothing is known about the functional significance of this receptor. Transcripts encoding the V2 receptor are only present at very low levels in the brain - but at high levels in the gills and kidney suggesting a role for this receptor in the maintenance of hydromineral balance (Lema 2010). A similar tissue distribution has been shown for a V2-type receptor transcript identified recently from African lungfish (Protopterus annectens; Konno et al. 2009). This V2-type receptor appears to play an important role in regulating kidney antidiuresis during the lungfish's terrestrial estivation life stage (Konno et al. 2010). Even less is known about the function of the IT receptor in fish, although transcripts for the IT receptor are present at high levels in the pupfish midbrain and appear to be regulated during osmotic challenge (Lema 2010). Clearly, future studies into the functions, patterns of brain distribution, and expressional regulation for both the V2 receptor for VT and the IT receptor are needed to better understand what role these receptors play in regulating the physiology and behavior of teleost fishes.

\section{Conclusions}

In this study, diurnal variation in the abundance of mRNAs encoding pro-VT and three VT receptors (V1a1, V1a2, and V2), as well as pro-IT and the IT receptor, were documented in the brains of wild Amargosa pupfish and examined relative to diel changes in pupfish behavior. The behavior of Amargosa pupfish was found to vary diurnally in accordance with changes in light intensity and temperature. In addition to these changes in behavior, transcripts encoding pro-VT, and the V1a2, $\mathrm{V} 2$, and IT receptors - but not pro-IT or the V1a1 receptor - were also found to vary over a diel cycle, with $\mathrm{mRNAs}$ for the $\mathrm{V} 1 \mathrm{a} 2$ receptor showing diurnal patterns that differed between males and females. Taken together, these findings demonstrate for the first time that transcript abundance for the $\mathrm{V} 1 \mathrm{a} 2$ and $\mathrm{V} 2$ receptors for $\mathrm{VT}$ show diurnal variation in the brain of fish.

\section{Acknowledgments}

This research was supported by funding from the University of North Carolina, Wilmington (UNCW). All procedures in this research followed the guidelines outlined by the Animal Care and Use Committee of UNCW (Protocol \#A0809-007). Collection of pupfish was conducted with the permission of the California Department of Fish and Game (801129-01) and the US Bureau of Land Management (CA-063.50). The authors thank Dr Kristin Hardy and two anonymous referees, whose comments greatly improved the quality of this manuscript. 


\section{References}

Adams CF, Foy RJ, Kelley JJ, Coyle KO. 2009. Seasonal changes in the diel vertical migration of walleye pollock (Theragra chalcogramma) in the northern Gulf of Alaska. Environ Biol Fish. 86(2):297-305.

Baker BI, Bird DJ, Buckingham JC. 1996. In the trout, CRH and AVT synergize to stimulate ACTH release. Reg Peptides. 67:207-210.

Balment RJ, Lu W, Weybourne E, Warne JM. 2006. Arginine vasotocin a key hormone in fish physiology and behaviour: a review with insights from mammalian models. Gen Comp Endocrinol. 147:9-16.

Barlow GW. 1958. Daily movements of desert pupfish, Cyprinodon macularius, in shore pools of the Salton sea, California. Ecology. 39(4):580-587.

Barlow GW. 1961. Social behavior of the desert pupfish, Cyprinodon macularius, in the field and in the aquarium. Amer Mid Nat. 65(2):339-359.

Blanco-Vives B, Sanchez-Vazquez FJ. 2009. Synchronisation to light and feeding time of circadian rhythms of spawning and locomotor activity in zebrafish. Physiol Behav. 98(3):268-275.

Brown JH, Feldmeth R. 1971. Evolution in constant and fluctuating environments: thermal tolerances of desert pupfish (Cyprinodon). Evolution. 25(2):390-398.

Caldwell HK, Albers EH. 2004a. Photoperiodic regulation of vasopressin receptor binding in female Syrian hamsters. Brain Res. 1002:136-141.

Caldwell HK, Albers EH. 2004b. Effect of photoperiod on vasopressin-induced aggression in Syrian hamsters. Horm Behav. 46:444-449.

Caldwell HK, Lee H-J, Macbeth AH, Young III WS. 2008a. Vasopressin: behavioral roles of an "original" neuropeptide. Prog Neurobiol. 84:1-24.

Caldwell HK, Smith DA, Albers EH. 2008b. Photoperiodic mechanism controlling scent marking: interactions of vasopressin and gonadal steroids. Eur J Neurosci. 27:1189-1196.

Delville Y, Mansour KM, Ferris CF. 1996. Testosterone facilitates aggression by modulating vasopressin receptors in the hypothalamus. Physiol Behav. 60:25-29.

Dewan AK, Maruska KP, Tricas TC. 2008. Arginine vasotocin neuronal populations among congeneric territorial and shoaling reef butterflyfishes: species, sex and reproductive season comparisons. J Neuroendocrinol. 20:1382-1394.

Duarte G, Segura-Noguera MM, Martin del Rio MP, Mancera JM. 2001. The hypothalamohypophyseal system of the white sea bream Diplodus sargus: immunocytochemical identification of arginine vasotocin, isotocin, melanin-concentrating hormone and corticotrophin-releasing factor. Histochem J. 33:569-578.

Duncan MJ, Cheng X, Heller KS. 1995. Photoperiodic exposure and time of day modulate the expression of arginine vasopressin mRNA and vasoactive intestinal peptide mRNA in the suprachiasmatic nuclei of Siberian hamsters. Brain Res Mol Brain Res. 32:181-186.

Falcón J, Besseau L, Sauzet S, Boeuf G. 2007. Melatonin effects on the hypothalamo-pituitary axis in fish. Trends Endocrinol Metabol. 18(2):81-88.

Falcón J, Migaud H, Muñoz-Cueto JA, Carrillo M. 2010. Current knowledge on the melatonin system in teleost fish. Gen Comp Endocinol. 165:469-482.

Feldmeth CR. 1981. The evolution of thermal tolerance in desert pupfish (genus: Cyprinodon). In: Naiman RJ, Soltz DL, editors. Fishes in North American deserts. New York: John Wiley \& Sons, Chapter 11. p. 357-384.

Ferris CF, Melloni RH, Koppel G, Perry KW, Fuller RW, Delville Y. 1997. Vasopressin/ serotonin interactions in the anterior hypothalamus control aggressive behavior in golden hamsters. J Neurosci. 17:4331-4340.

Ferris CF, Potegal M. 1988. Vasopressin receptor blockage in the anterior hypothalamus suppresses aggression in hamsters. Physiol Behav. 44:235-239.

Foran CM, Bass AH. 1998. Preoptic AVT immunoreactive neurons of a teleost fish with alternative reproductive tactics. Gen Comp Endocrinol. 111:271-282. 
Fraser NHC, Metcale NB, Thorpe JE. 1993. Temperature-dependent switch between diurnal and nocturnal foraging in salmon. Proc Roy Soc Lond B. 252(1334):135-139.

Gilchriest BJ, Tipping DR, Hake L, Levy A, Baker BI. 2000. The effects of acute and chronic stresses on vasotocin gene transcripts in the brain of the rainbow trout (Oncorhynchus mykiss). J Neuroendocrinol. 12:795-801.

Gilchriest BJ, Tipping DR, Levy A, Baker BI. 1998. Diurnal changes in the expression of genes encoding for arginine vasotocin and pituitary pro-opiomelanocortin in the rainbow trout (Oncorhynchus mykiss): correlation with changes in plasma hormones. J Neuroendocrinol. 10:937-943.

Godwin J, Sawby R, Warner RR, Crews D, Grober MS. 2000. Hypothalamic arginine vasotocin mRNA abundance variation across sexes and with sex change in a coral reef fish. Brain Behav Evol. 55:77-84.

Goodson JL, Bass AH. 2000. Forebrain peptides modulate sexually polymorphic vocal circuitry. Nature. 403:769-772.

Goodson JL, Bass AH. 2001. Social behavior functions and related anatomical characteristics of vasotocin/vasopressin systems in vertebrates. Brain Res Rev. 35:246-265.

Goossens N, Dierickx K, Vandesande F. 1977. Immunocytochemical localization of vasotocin and isotocin in the preopticohypophysial neurosecretory system of teleosts. Gen Comp Endocrinol. 32:371-375.

Gozdowska M, Kleszczyńska A, Sokolowska E, Kulczykowska E. 2006. Arginine vasotocin (AVT) and isotocin (IT) in fish brain: diurnal and seasonal variations. Comp Biochem Physiol B. 143:330-334.

Greenwood AK, Wark AR, Fernald RD, Hofmann HA. 2008. Expression of arginine vasotocin in distinct preoptic regions is associated with dominant and subordinate behaviour in an African cichlid fish. Proc Roy Soc B. 275(1649):2393-2402.

Grober MS, George AA, Watkins KK, Carneiro LA, Oliveira RF. 2002. Forebrain AVT and courtship in a fish with male alternative reproductive tactics. Brain Res Bull. $57: 423-425$.

Hansen EA, Closs GP. 2005. Diel activity and home range size in relation to food supply in a drift-feeding stream fish. Behav Ecol. 16(3):640-648.

Helfman GS. 1993. Fish behaviour by day, night and twilight. In: Pitcher TJ, editor. Behaviour of teleost fishes. London: Chapman and Hall. p. 479-512.

Hibino M, Ohta T, Isoda T, Nakayama K, Tanaka M. 2006. Diel and tidal changes in the distribution and feeding habits of Japanese temperate bass Lateokabrax japonicus juveniles in the surf zone of Ariake Bay. Ichthyol Res. 53(2):129-136.

Hontela A, Lederis K. 1985. Diel variations in arginine vasotocin content of goldfish brain and pituitary: effects of photoperiod and pinealectomy. Gen Comp Endocrinol. 57:397-404.

Itzkowitz M. 1974. The effects of other fish on the reproductive behavior of the male Cyprinodon variegatus (Pisces: Cyprinodontidae). Behaviour. 48:1-21.

James CJ. 1969. Aspects of the ecology of the Devil's Hole pupfish, Cyprinodon diabolis [MS thesis]. [Las Vegas (NV)]: University of Nevada.

Kadri S, Metcalfe NB, Huntingford FA, Thorpe JE. 1997. Daily feeding rhythms in Atlantic salmon II: size-related variation in feeding patterns of post-smolts under constant environmental conditions. J Fish Biol. 50:273-279.

Kalamatianos T, Kallo I, Coen CW. 2004. Ageing and the diurnal expression of the mRNAs for vasopressin and for the $\mathrm{V}_{1 \mathrm{a}}$ and $\mathrm{V}_{1 \mathrm{~b}}$ vasopressin receptors in the suprachiasmatic nucleus of male rats. J Neuroendocrinol. 16(6):493-501.

Kodric-Brown A. 1978. Establishment and defense of breeding territories in a pupfish (Cyprinodontidae: Cyprinodon). Anim Behav. 26:818-834.

Kodric-Brown A. 1981. Variable breeding systems in pupfish (genus: Cyprinodon): adaptations to changing environments. In: Naiman RJ, Soltz DL, editors. Fishes in North American deserts. New York: John Wiley \& Sons, Chapter 7. p. 205-235. 
Konno N, Hyodo S, Yamaguchi Y, Kaiya H, Miyazato M, Matsuda K, Uchiyama M. 2009. African lungfish, Protopterus annectens, possess an arginine vasotocin receptor homologous to the tetrapod V2-type receptor. J Exp Biol. 212:2183-2193.

Konno N, Hyodo S, Yamaguchi Y, Matsuda K, Uchiyama M. 2010. Vasotocin/V2-type receptor/aquaporin axis exists in African lungfish kidney but is functional only in terrestrial condition. Endocrinol. 151:1089-1096.

Kulczykowska E. 1999. Diel changes in plasma arginine vasotocin, isotocin, and melatonin in rainbow trout (Oncorhynchus mykiss). Fish Physiol Biochem. 21:141-146.

Kulczykowska E, Stolarski J. 1996. Diurnal changes in plasma vasotocin and isotocin in rainbow trout adapted to fresh water and brackish Baltic water. Gen Comp Endocrinol. 104:197-202.

Kulczykowska E, Warne JM, Balment RJ. 2001. Day-night variations in plasma melatonin and arginine vasotocin concentrations in chronically cannulated flounder (Platichthys flesus). Comp Biochem Physiol. A. 130:827-834.

Larson ET, O'Malley DM, Melloni Jr RH. 2006. Aggression and vasotocin are associated with dominant-subordinate relationships in zebrafish. Behav Brain Res. 167:94-102.

Leiser JK. 2003. When are neighbors 'dear enemies' and when are they not? The responses of territorial male variegated pupfish, Cyprinodon variegatus, to neighbors, strangers and heterospecifics. Anim Behav. 65:453-462.

Leiser JK, Itzkowitz M. 2003. The breeding system of an endangered pupfish (Cyprindon elegans). Wester N Amer Nat. 63(1):118-121.

Lema SC. 2006. Population divergence in plasticity of the AVT system and its association with aggressive behaviors in a Death Valley pupfish. Horm Behav. 50:183-193.

Lema SC. 2008. The phenotypic plasticity of Death Valley's pupfish. Amer Sci. 96:28-36.

Lema SC. 2010. Identification of multiple vasotocin receptor cDNAs in teleost fish: sequences, phylogenetic analysis, sites of expression, and regulation in the hypothalamus and gill in response to acute hyperosmotic challenge. Mol Cell Endocrinol. 321:215-230.

Lema SC, Nevitt GA. 2004a. Exogenous vasotocin alters aggression during agonistic exchanges in male Amargosa River pupfish (Cyprinodon nevadensis amargosae). Horm Behav. 46:628-637.

Lema SC, Nevitt GA. 2004b. Variation in vasotocin immunoreactivity in the brain of recently isolated populations of a Death Valley pupfish, Cyprinodon nevadensis. Gen Comp Endocrinol. 135:300-309.

Li J-D, Burton KJ, Zhang C, Hu S-B, Zhou Q-Y. 2009. Vasopressin receptor V1a regulates circadian rhythms of locomotor activity and expression of clock-controlled genes in the suprachiasmatic nuclei. Am J Physiol Regul Comp Physiol. 296:R824-R830.

Liu RK. 1969. The comparative behavior of allopatric species (Teleostei - Cyprinodontidae: Cyprinodon) [PhD thesis]. [Los Angeles (CA)]: University of California.

Mahoney MM, Ramanathan C, Hagenauer MH, Thompson RC, Smale L, Lee T. 2009. Daily rhythms and sex differences in vasoactive intestinal polypeptide, VIPR2 receptor and arginine vasopressin mRNA in the suprachiasmatic nucleus of a diurnal rodent, Arvicanthis niloticus. Eur J Neurosci. 30:1537-1543.

Mihai R, Coculescu M, Wakerley JB, Ingram CD. 1994. The effects of $\left[\operatorname{Arg}^{8}\right]$ vasopressin and $\left[\mathrm{Arg}^{8}\right]$ vasotocin on the firing rate of suprachiasmaic neurons in vitro. Neurosci. 62(3):783-792.

Miranda JA, Oliveira RF, Carneiro LA, Santos RS, Grober MS. 2003. Neurochemical correlates of male polymorphism and alternative reproductive tactics in the Azorean rock-pool blenny, Parablennius parvicornis. Gen Comp Endocrinol. 132:183-189.

Patchev VK, Almeida OF. 1995. Corticosteroid regulation of gene expression and binding characteristics of vasopressin receptors in the rat brain. Eur J Neurosci. 7:1579-1583.

Pister EP. 1981. The conservation of desert fishes. In: Naiman RJ, Soltz DL, editors. Fishes in North American deserts. New York: John Wiley \& Sons, Chapter 13. p. 411-445. 
Pfaff MW. 2001. A new mathematical model for relative quantification in realtime RT-PCR. Nuc Acids Res. 29:2002-2007.

Raney EC, Backus RH, Crawford RW, Robins CR. 1953. Reproductive behavior in Cyprinodon variegatus Lacépède, in Florida. Zoologica. 38:97-104.

Rasmussen R. 2000. Quantification on the LightCycler. In: Meuer S, Wittwer C, Nakagawara K, editors. Rapid cycle real-time PCR, methods and applications. Heidelberg: Springer Press. p. 21-34.

Reebs SG. 2002. Plasticity of diel and circadian activity rhythms in fishes. Rev Fish Biol Fish. 12(4):349-371.

Saito D, Shi Q, Ando H, Urano A. 2004. Attenuation of diurnal rhythms in plasma levels of melatonin and cortisol, and hypothalamic contents of vasotocin and isotocin mRNAs in pre-spawning chum salmon. Gen Comp Endocrinol. 137:62-68.

Salek SJ, Sullivan CV, Godwin J. 2002. Arginine vasotocin effects on courtship behavior in male white perch (Morone americana). Behav Brain Res. 133:177-183.

Santangelo N, Bass AH. 2006. New insights into neuropeptide modulation of aggression: field studies of arginine vasotocin in a territorial tropical damselfish. Proc $\mathrm{R}$ Soc $\mathrm{B}$. 273:3085-3092.

Schoenherr AA. 1981. The role of competition in the replacement of native fishes by introduced species. In: Hocutt $\mathrm{CH}$, Wiley EO, editors. Fishes in North American deserts. New York: John Wiley \& Sons, Chapter 6. p. 173-203.

Scoppettone GG, Rissler PH, Gourley C, Martinez C. 2005. Habitat restoration as means of controlling non-native fish in a Mojave Desert oasis. Restoration Ecol. 13(2):247-256.

Semsar K, Kandel FLM, Godwin J. 2001. Manipulations of the AVT system shift social status and related courtship and aggressive behavior in the bluehead wrasse. Horm Behav. 40:21-31.

Smith GW, Glass CW, Johnstone ADF, Mojsiewicz WR. 1993. Diurnal patterns in the spatial relationships between saithe, Pollachius virens, schooling in the wild. J Fish Biol. 43(suppl. A):315-325.

Sogard SM, Olla BL. 1996. Diel patterns of behavior in juvenile walleye Pollock, Theragra chalcogramma. Environ Biol Fish. 47(4):379-386.

Soltz DL. 1974. Variation in life history and social organization of some populations of Nevada pupfish, Cyprinodon nevadensis [PhD thesis]. [Los Angeles (CA)]: University of California.

Soltz DL, Naiman RJ. 1978. The natural history of native fishes in the Death Valley system. Nat Hist Mus Los Angeles County Sci Ser. 30:1-76.

Thompson RR, Walton JC. 2004. Peptide effects on social behavior: effects of vasotocin and isotocin on social approach behavior in male goldfish (Carassius auratus). Behav Neurosci. 118(3):620-626.

Thurow RF. 1997. Habitat utilization and diel behavior of juvenile bull trout (Salvelinus confluentus) at the onset of winter. Ecol Fresh Fish. 6:1-7.

Tominaga K, Shinohara K, Otori Y, Fukuhara C, Inouye ST. 1992. Circadian rhythms of vasopressin content in the suprachiasmatic nucleus of the rat. NeuroReport. 3:809-812.

Uhl GR, Reppert SM. 1986. Suprachiasmatic nucleus vasopressin messenger RNA: circadian variation in normal and Brattleboro rats. Science. 232:390-393.

Van Den Dungen HM, Buijs RM, Pool CW, Terlou M. 1982. The distribution of vasotocin and isotocin in the brain of the rainbow trout. J Comp Neurol. 212:146-157.

Walton JC, Waxman B, Hoffbuhr K, Kennedy M, Beth E, Scangos J, Thompson RR. 2010. Behavioral effects of hindbrain vasotocin in goldfish are seasonally variable but not sexually dimorphic. Neuropharmacology. 58(1):126-134.

Warne J. 2002. The role of arginine vasotocin in teleost fish osmoregulation. In: Hazon N, Flick G, editors. Osmoregulation and drinking in vertebrates. Oxford (UK): BIOS Scientific Publishers, Ltd, Chapter 6. p. 83-95. 
Watters JJ, Wilkinson CW, Dorsa DM. 1996. Glucocorticoid regulation of vasopressin $\mathrm{V}_{1 \mathrm{a}}$ receptors in rat forebrain. Mol Brain Res. 38:276-284.

Yambe Y, Arima H, Kakiya S, Murase T, Oiso Y. 2002. Diurnal changes in arginine vasopressin gene transcription in the rat suprachiasmatic nucleus. Mol Brain Res. 104:132-136.

Young LJ, Wang Z, Cooper TT, Albers HE. 2000. Vasopressin receptor (V1a) binding, mRNA expression and transcriptional regulation by androgen in the Syrian hamster brain. J Neuroendocrinol. 12:1179-1185. 